DOI https://doi.org/10.18551/rjoas.2021-01.01

\title{
COMPARING EFFICIENCY OF SAVING AND CREDIT COOPERATIVES OWNED BY GOVERNMENT EMPLOYEES AND GENERAL PUBLIC IN JAKARTA: A DATA ENVELOPMENT ANALYSIS APPROACH
}

\author{
Sudarmadji ${ }^{1}$, Samryn L.M. ${ }^{2}$, Baskoro B.D. ${ }^{1 *}$ \\ ${ }^{1}$ Sekolah Tinggi Manajemen Labora, Jakarta, Indonesia \\ ${ }^{2}$ University of Tanri Abeng, Jakarta, Indonesia \\ *E-mail: bimmodibi@gmail.com \\ ORCID: 0000-0002-1209-0483
}

\begin{abstract}
Cooperatives have an essential role in Indonesian economy due to their contribution to the provision of capital within employees and societies. The government of Indonesia makes it easier to establish cooperatives, causing the number of cooperatives to increase over time. Therefore, it becomes necessary to study the effectiveness and efficiency of their resource management. This study aims to examine the efficiency of cooperatives in terms of input variables, namely members, total capital, and operational costs and output variables, namely profits, assets, loans, and debt repayments. The saving and credit cooperatives used in this study are owned by government employees (first type) and the general public (second type). 22 cooperatives based in DKI Jakarta were taken as the sample of this study. 11 of them are owned by government employees, and the remaining 11 were managed by the general public. The efficiency of these two types of cooperatives was analyzed separately and then compared using the Data Envelopment Analysis (DEA) method. The findings of this research indicated that the average efficiency of the first type of cooperatives was smaller than that of the second. This means that those saving and credit cooperatives have yet to reach the maximum level of efficiency according to the input and output variables. However, the average value of efficiency of those cooperatives is at a good level. Besides, the results of this research also showed that the cooperatives established by the general public had higher efficiency than the cooperatives possessed by government employees.
\end{abstract}

\section{KEY WORDS}

Cooperatives, efficiency, Data Envelopment Analysis (DEA).

In Indonesia, cooperatives emerge as a form of family-based community economic development movement. The main objective of the establishment is to improve the welfare of cooperative members, while the general objective is to develop the economy of the nation and state of Indonesia in order to become a just and prosperous society. Cooperatives are normally established by groups of people or cooperative legislative bodies with cash donations from their members as the capital to carry out their business activities in line with the objectives and principles set by them.

Cooperatives are principally established to build and develop the economic potential and capabilities of their members. As regards with the economic and social welfare, cooperatives participate actively in improving the quality of life, strengthening the people's economy, and sustaining the strength and resilience of the country's economy. In addition, cooperatives take part in creating and developing the country's economy with family-based joint efforts and economic democracy (Mhembwe \& Dube, 2017).

The focus of this research is on saving and credit cooperatives based in Jakarta, Indonesia. The specific objective of such cooperatives is to provide services and products to people with a low economic status living in both urban and rural areas. In general, saving and credit cooperatives have shared goals and characteristics with other financial organizations such as People's Loan Banks (BPR) and conventional banks. Saving and credit cooperatives also have the primary goal to provide continuous service to their members for the sake of social development. They are meant to improve the public welfare 
by providing loans to both members and non-members of the society. Therefore, it is expected that the provision of loans can help lenders' businesses to grow, thus allowing for job creation which will reduce unemployment and poverty rates.

As stated by the Minister of Cooperatives, Syarif Hasan, in 2014, the growth of cooperatives, along with micro, small, and medium enterprises (MSMEs), can reduce unemployment and poverty in Indonesia. In relation to this, the number of SMEs is currently standing at 56.5 million units, and $98.9 \%$ of them are micro enterprises. In the meantime, the number of cooperatives in Indonesia is 200,808 units. The increasing figures of cooperatives and MSMEs will undoubtedly lead to reduction in poverty and unemployment. Apart from that, the number of debtors from cooperatives and SMEs is 10.04 million people. Given this figure, the Ministry of Cooperatives and SMEs will continue to stimulate the establishment of new cooperatives and SMEs throughout Indonesia. If all cooperatives, serving as as micro economic units, are successful, they will turn into an economic movement which can make a significant contribution to improving the people's economic standard of living and enhancing the country's economic development.

The average growth rate of cooperatives from varying business groups in Indonesia at a period of $2008-2015$ was $5.07 \%$ per year. However, not all cooperatives formed were able to run smoothly.

Saving and credit cooperatives are financial institutions that make contribution to the Indonesian economy as a whole. Due to the rapid development of saving and credit cooperatives and the attention of the government to them, the law concerning cooperatives was then issued, namely Law Number 17 of 2012. In particular, the law emphasizes the importance of channeling loans to people. Below is the data regarding the channeling of credits to micro, small, and medium enterprises (MSMEs).

An organization needs resources in carrying out its activities to achieve the goals set. One of the ways to find out whether it has carried out its operational activities according to the objective is to examine its performance. This can done by looking at the use and management of organizational resources. As a source of company performance information, financial reports have to reflect the actual state of the organization within a certain period of time (Santoso \& Sukihanjani, 2013). This is caused by the fact that saving and credit cooperatives should gain trust from their members as consumers and owners in order to make them feel safe and get good service as expected by them and other communities. Saving and credit cooperatives should be able to prove their performance through the services provided. Besides, they need to act as intermediary organizations between members and owners as well as sources of funds and users of funds and fulfill a strategic function in advancing the economic growth of people. This strategic role further requires the continuity of the companies to be maintained in order to function properly. Consequently, the performance of such cooperatives needs to be paid attention (Mulyono, 2012).

The financial performance of saving and credit cooperatives is considered by all related parties, including owners, people, and the government. As a result, it is important for them to apply the principle of vigilance in the financial control and risk management. One of the critical aspects for measuring the financial performance is through the efficiency of the financial management in generating cooperative profits (Firdaus \& Susanto, 2002).

Efficiency is a parameter which is commonly used to address various difficulties in calculating the performance. Saving and credit cooperatives are financial organizations that have risks, so they have to minimize the level of risks in question. Therefore, they are required to act rationally in overcoming the issues related to the efficieny of risk management (Hendar, 2010).

Saving and credit cooperatives are responsible for ensuring that funds sourced from their members acting as both consumers and owners are channelled carefully, precisely, and efficiently. Therefore, efficiency serves as an essential indicator for analyzing the efficiency of financial policies used to produce the maximum outputs from given inputs to achieve the predetermined goal (Hendar \& Kusnadi, 2005).

Based on the explanation mentioned above, the objectives of this study are: (1) to determine the effect of members, capital, and operational costs on the efficiency of saving 
and credit cooperatives owned by government employees and the general public in terms of profits, assets, loan amounts, and debt repayments; and (2) to compare and measure the efficiency of cooperatives owned by government employees and the general public.

\section{LITERATURE REVIEW}

Efficiency is used in many aspects, such as economics, technologies, and social sciences (Coelli et al., 2005). In the perspective of economy, efficiency can be used to measure a company. A company is considered to be efficient if it produces the maximum outputs with the minimal inputs (Titko \& Jureviciene, 2014).

The efficiency of financial institutions has been a key issue in economic transitions (Jemric \& Vujcic, 2002). The efficiency of such institutions has been measured in recent decades as to manage, supervise, and monitor their business activities. Financial industry is one of the industries that have a direct impact on the economy. Thus, it is essential to assess the level of efficiency of financial institutions in the economy (Mamatzakis, Tsionas, Kumbhakar, \& Koutsomanoli-Filippaki, 2015).

The concept of efficiency orginally comes from the concept of micro economy, namely consumer and producer theories. In the theories, consumers attempt to maximize utility or achieve satisfaction, while producers try to maximize profits or minimize costs. In the producer theory, there are frontier production lines that describe the relationship between the inputs and outputs of the production process and production boundaries that represent the maximum output of each input consumed. This appears to be a technology used by a business or industry (Ascarya, Achsani, Yumanita, \& Rokhimah, 2009).

According to Karimah, Novianti, \& Effendi (2016), there are three approaches used to define the relationship between the inputs and outputs in the financial activities of a financial institution. First, the asset approach is the primary function of a financial institution as a credit creator and a credit output. Second, the production approach assumes that a financial institution functions as an issuer of loans and its output as a combined unit of energy and capital expenditures on fixed assets. This approach further reflects the activities of a financial institution as a service producer to depositors and borrowers by using all production factors such as labour and economic resources. This approach was initially introduced by Benston, Hunter, \& Wall (1995), who considered a financial institution as a saving account generator for depositors and a lender for borrowers. In other words, it refers inputs to a combined unit of labor, capital costs, fixed assets, and other materials and outputs to a combined unit of deposit accounts or other related transactions. Third, the intermediation approach refers a financial institution to an intermediary, by adding and takes over financial assets from surplus units to deficit units. In this approach, inputs relate to labor costs and deposit payment capital, and outputs to loans and financial investments. As said by Demirbag et al. (2010), performance can be measured by calculating productivity, namely the ratio between outputs and inputs, and efficiency is the ability to produce what connects inputs to outputs.

The theoretical or empirical evaluation of organizational performance is dominated by the use of frontier methods. These methods are generally divided into two groups: parametric and nonparametric. They have similar characteristics in the application of relative efficiency as performance measurement. The efficiency of a Decision Maker Unit (DMU) is viewed as the ability to produce maximum outputs from minimum inputs, according to resource constraints and operating environment (Banker, Charnes, \& Cooper, 1984; Majid \& Sufian, 2006). Normally, Stochastic Frontier Analysis (SFA) is used in the parametric approach, while Data Envelopment Analysis (DEA) is utilized for the nonparametric approach.

Firstly introduced in 1978, the DEA method is getting populer. This approach is widely used to estimate efficiency in banking studies. It uses linear programming procedures to identify empirical products. The DEA method compares all units with similarity by taking into account a number of input and output dimensions together. The DEA method developed by Charnes, Cooper, \& Rhodes is also known as the CCR method (Charnes, Cooper, \& Rhodes, 1978), and the method introduced by Banker, Charnes, and Cooper is termed as 
the BCC method (Banker et al., 1984). Due to the flexibility of the method and the limited sources of the data, this research chose the DEA as a method to measure efficiency.

Empirical studies into the measurement of efficiency have been carried out using both DEA and SFA, following that these methods are well developed and most widely used to analyze the competence of financial institutions, particularly in the United States and developing countries. An example of using these methods in research into the efficiency of financial institutions can be seen from Berger \& Humphrey (1997). Besides this, the use of the methods also appear in the previous studies conducted by Kuosmanen, Saastamoinen, \& Sipiläinen, (2013), Oh \& Shin (2015), and Ueasin, Liao, \& Wongchai, (2015).

Measuring the efficiency of financial institutions such as saving and credit cooperatives can be conducted by examining their operational sides, a primary approach used to describe the relationship between inputs and outputs. In this regard, there are two approaches that can be adopted, namely production and mediation (Freixas \& Rochet, 1998). The production approach describes activities as the production of services to depositors and borrowers based on all factors of production available such as labour and physical capital. This approach is initiated by Benston et al. (1995), who viewed a financial institution as a financial hub which provides deposit accounts for deposits and loans. Therefore, this approach reflects inputs as a combined unit of labor, capital costs, fixed assets, and other materials and outputs as a combined unit of deposit accounts.

Saad and Moussawi (2009) mentioned that the production approach looks into the actions of financial institutions to offer cost-based products and services to customers with multiple sources. This approach is utilized to figure out the efficiency of costs since the operational costs of financial institutions are taken into consideration. For the intermediate approach, a financial institution is seen as a financial intermediary that collects funds in the form of deposits and provides loans or other assets to gain income. This approach is largely used to analyze the organizational efficiency and economic qualifications of financial institutions.

Previously, there were a number of studies carried out into the efficiency of financial institutions. Those studies can further be divided into three groups. The first group focused on evaluating the efficiency of Islamic financial institutions as done by Ascarya et al. (2009), Majid \& Sufian (2006), and Saeed et al. (2013). The second group was meant to evaluate the efficiency of conventional financial institutions such as those conducted by Gunawan (2016), Ivan (2015), Sokic (2015), and Zuhroh, Ismail, \& Maskie (2015). The third group aimed to compare the efficiency of Islamic financial institutions with that of conventional financial institutions as conducted by Al-Jarrah \& Molyneux (2006), and Ferhi \& Chkoundali (2015). Based on these studies, it was found that the frontier method seems to be superior because of the use of programming or statistical techniques and the provision of more accurate estimates. Therefore, the frontier competency analysis has been widely accepted and used.

Data Envelopment Analysis (DEA) is an approach based on linear programming principles. Introduced by Charles et al. (1978), it refers to the concept of performance (Farrel, 1957). This approach is used to measure the relative efficiency of a Decision Maker Unit (DMU). All deviations resulting from estimated production limits are expressed as inefficiencies, and a DMU is a combination of varied inputs and outputs (Berger \& Humphrey, 1997).

The estimation of the DEA efficiency for a decision-making unit (DMU) with the assumption of constant returns to scale (CRS) is initially developed by Charnes et al. (1978) and is later often referred to as the Charnes-Cooper-Rhodes (CCR) method. Computational efficiency for a DMU using the CCR method is found to be a solution put forward for linear programming (Cooper et al. 2006). This method introduces the measurement for the efficiency of a DMU, which is the maximum ratio between outputs and surplus inputs. The weight value used in the ratio is determined by the constraint, where the ratio for each DMU must have a value less than or equal to 1 . The DEA method with multiple inputs and outputs requires the linear programming technique. The functional objective of each fractional linear program is the ratio between the outputs and the DMUs divided by the inputs. 
The CCR method is known as the Constant Returns to Scale (CRS), which refers to the ratio between constant output and input values and between comparable input and output values. Unlike the Banker-Charnes-Cooper Institution (BCC) method, the CCR method has no convexity problem.

The DEA method providing variable returns to scale is called the BCC method (BankerCharnes-Cooper, 1984). Also known as the Variable Return To Scale (VRS) method, this method is by improving inputs and outputs with unequal proportion. The increased level can be either Increasing Return to Scale (IRS) or Decreasing Return to Scale (DRS). The DEA method has been extensively used in the previous research, especially on analyzing financial institutions. Sherman and Gold (1985) were the first researchers to adopt the DEA to calculate the scores of efficiency of financial institutions. Bhattacharyya et al. (1997) employed the VRS to study commercial financial institutions in India between 1986 and 1991 within the framework of a frontier approach based on the data of the institutions collected over years.

In the past, there was an increasing number of studies which used the DEA to measure the efficiency of financial institutions through their operations. Some of the studies were carried out by Abdul Rahman Ali (2017), Anita Puspita Sari (2017), Heny Yuningrum (2016), Marwa and Aziakpono (2016), Solikah Yunita Utami (2010), Darrat et al. (2002), Sathye (2001), Sturm and Willian (2004), Ayadi et al. (1998), Barr et al. (2002), Isik and Hassan (2003), and Mukherjee A. et al. (2002). Besides the efficiency, the competency of such institutions was also examined, including Al-Faraj et al. (1992), Oral et al. (1992), Drake and Howcroft (2002), and Paradi \& Schffnit (2004).

Saving and credit cooperatives are financial institutions that implement an intermediary approach by taking savings from surplus units to channel financing. Berger \& Humphrey (1997) stated that the production approach is better for assessing the efficiency of branches of financial institutions than the mediation approach as seen from the previous studies by Paradi and Schaffnit (2004), Pasiouras et al. (2007), and Saad and Mousawi (2009). The data processing was performed using the DEAFrontier program developed by Zhu (2009). An empirical study by Marwa (2016) with the DEA method using a sample of 103 saving and credit cooperatives resulted in $42 \%$ for the technical efficiency, $52 \%$ for the pure technical efficiency, and $76 \%$ for the scale efficiency. On the other hand, the research conducted by Yusniar et al. (2007) on 8 saving and credit cooperatives using the DEA method found that 3 cooperatives succeeded to achieve the efficiency value of $100 \%$, namely KSP Bhakti Warga, KSP Mulya Abadi, and KSP Mitra Abadi, while 5 cooperatives only reached the efficiency values of below 60\%, namely KSP Sejahtera Abadi (35,09\%), KSP Rukun (25,37\%), KPS Gotong Royong (39,41\%), KPS Adil Makmur (53,26\%), and KSP Usaha Bersama $(29,31 \%)$. The results also indicated that there was a substantial correlation of $80 \%$ with a significant level of 0.0017 , which is smaller than the alpha value of 0.05 .

Another study was done by Utami (2010), who used the DEA to evaluate 10 saving and credit cooperatives located in Klaten Regency, Central Java. In the study, the input variables included cost, capital, and total management, whereas the output variable was only the amount of profits. The findings of this study showed that 3 cooperatives were efficient, and 7 cooperatives were inefficient. The inefficiency was adherent to the management costs $(45.25 \%)$, management issues $(45.23 \%)$, and the capital $(39.26 \%)$. The inefficient cooperatives were KPRI Vorstenlanden (45.81\%), KPRI Padma Wijaya (50.67\%), KPRI Tulus Bhakti (28.12\%), KPRI Bina Sejahtera (68.80\%), KPRI SMP N 1 Karanganom (40.77\%), KPRI Adil Sejahtera (80.77\%), and KPRI Maratani (21.20\%).

\section{METHODS OF RESEARCH}

The data used in this research was secondary data. The data was obtained from the financial reports of saving and credit cooperatives based in DKI Jakarta. The data was also collected through literature review by reading the sources related to the subject being studied. The reports obtained were then also compared to the sources available in the library. The sample used in this research was 22 cooperatives which are based in DKI 
Jakarta. 11 cooperatives are owned by government employees, and the rest are formed by the general public. The data of these cooperatives is given in Table 1. The selection of the sample was based on the predetermined provision that each selected cooperative should comply with the documentation requirements set by the government in terms of two copies of Cooperative Establishment Deeds, Cooperative Establishment Meeting Reports, and Annual Financial Reports. These documents should be reported and organized for members and government cooperative offices and include a list of attendees in the establishment meetings.

Table 1 - List of Saving and Loan Cooperatives in Jakarta (2015)

\begin{tabular}{|l|l|l|l|}
\hline No. & Cooperative Name & Location & Ownership \\
\hline 1 & KPRI RSJ Dr. Suharto Heerjan & West Jakarta & Government employees \\
\hline 2 & KPRI Rumah Sakit Pelni & West Jakarta & Government employees \\
\hline 3 & KPRI Primier Mandiri Sejahtera & West Jakarta & Government employees \\
\hline 4 & KPRI Perum Peruri & South Jakarta & Government employees \\
\hline 5 & KPRI Departemen Agama Jakarta Selatan & South Jakarta & Government employees \\
\hline 6 & KPRI Dinas Kebersihan & East Jakarta & Government employees \\
\hline 7 & KPRI Sekjen Kementerian Pendidikan and Kebudayaan & Central Jakarta & Government employees \\
\hline 8. & KPRI Kementerian Agama RI & Jakarta Pussat & Government employees \\
\hline 9 & KPRI Primkopal Kolinlamil & North Jakarta & Government employees \\
\hline 10 & KPRI Guru and Karyawan SMA 45 & North Jakarta & Government employees \\
\hline 11 & KPRI Kawasan Berikat Nusantara & North Jakarta & Government employees \\
\hline 12 & KSP Sumber Jaya & North Jakarta & General public \\
\hline 13 & KSP Kodanoa & West Jakarta & General public \\
\hline 14 & KSP Sejati Mulya & South Jakarta & General public \\
\hline 15 & KSP Sehati & South Jakarta & General public \\
\hline 16 & KSP Rawa Badung & East Jakarta & General public \\
\hline 17 & KSP Wira Karya Jaya & East Jakarta & General public \\
\hline 18 & KSP Ceger & East Jakarta & General public \\
\hline 19 & KSP Tunas Jaya & Central Jakarta & General public \\
\hline 20 & KSP Kesejahteraan Kaum Ibu & Central Jakarta & General public \\
\hline 21 & KSP Kemauan Bersama & Central Jakarta & General public \\
\hline 22 & KSP Makmur & East Jakarta & General public \\
\hline
\end{tabular}

Source: Cooperative office of DKI Jakarta (2015).

Input and output variables were used in this research. In this regard, members, capital, and operational costs were chosen for the input variables, while profits, assets, member loans, and loan repayments from members were selected for the output variables.

A descriptive analysis was carried out in this study to determine the maximum, minimum, average, and standard deviation values of the efficiency of saving and credit cooperatives using the SPSS software.

The DEA method assumes that $\mathrm{N}$ is a saving and credit cooperative or a Decision Maker Unit (DMU) with the output variables including profits, assets, loans, and debt repayments and the input variables consisting of members, capital, and operational costs. As regards with the efficiency, it is measured as follows:

$$
e f_{p}=\frac{\sum_{i-1}^{n} u_{i} y_{i p}}{\sum_{j=1}^{t} v_{j} x_{j p}}
$$

Note: yip is i as the outputs (profits, assets, loans, and debt repayments) generated by $p$ DMU; $x j p$ is $j$ as the inputs (members, capital, operating costs) used by $p$ DMU; ui is the output weight; $v j$ is the input weight, $i$ from 1 to $s$ and $j$ from 1 to t. The ratio of efficiency is subject to the equation below: 


$$
\frac{\sum_{i=1}^{n} u_{i} y_{i p}}{\sum_{j=1}^{t} v_{j} \cdot x_{j p}} \leq 1 \text { where } \mathrm{i}=1 \ldots . \mathrm{n} \text {, and } \mathrm{u}_{\mathrm{i}} \text { and } \mathrm{v}_{\mathrm{j}} \geq 0 \text { (2) }
$$

The first inequality ensures that the efficiency ratio of a DMU cannot exceed a value of 1 , while the second inequality requires a positive weight value. The weight of each output and input needs to be measured to allow each DMU to reach the maximum efficiency ratio. In this case, the DEA gives benefit to each DMU in terms of the efficiency ratio.

The CCR method applies as follows:

$$
\begin{aligned}
& \sum_{j=1}^{n} x i j \geq \theta i \quad \ldots \ldots \ldots \ldots \ldots . . \mathrm{i}=1,2 \ldots ., \mathrm{m} \\
& \sum_{j=1}^{n} y r j \lambda j \leq y i \quad \ldots \ldots \ldots \ldots . \mathrm{r}=1,2 \ldots ., \mathrm{s} \\
& \sum_{j=1}^{n} \lambda_{j} \geq 0 \ldots \ldots \ldots \ldots \ldots . \mathrm{j}=1,2
\end{aligned}
$$

Note:

$\theta=$ efficiency of DMU with CCR method;

$\mathrm{N}=$ total DMUs;

$M=$ total inputs (members, capital, and operating costs);

$\mathrm{S}=$ total outputs (profits, assets, loans, and debt repayments);

$\mathrm{Xij}=$ total inputs to i DMU j;

$\mathrm{yrj}=$ total outputs to $\mathrm{r} \mathrm{DMU} \mathrm{j}$;

$\lambda j=$ weight of DMU $\mathrm{j}$ for calculated DMU.

The CCR method is also known as the Constant Returns to Scale (CRS), which refers to the ratio between constant output and input values and between comparable input and output values. Unlike the Banker-Charnes-Cooper Institution (BCC) method, the CCR method has no convexity problem.

The DEA method providing variable returns to scale (RTS) is called the BCC method (Banker-Charnes-Cooper, 1984). This method is done by improving the convexity condition for the weight value $\lambda$ by entering the following limitation method:

$$
\sum_{j=1}^{n} \lambda_{j}=1
$$

Subsequently, the BCC method applies as follows:

$$
\begin{array}{ll}
\sum_{j=1}^{n} x_{i j} \lambda_{\mathrm{ij}} \geq \pi \mathrm{i} & \mathrm{i}=1,2, ., \mathrm{m} \\
\sum_{j=1}^{n} y r \lambda_{\mathrm{j} \leq \mathrm{yi}} & \mathrm{r}=1,2, . . \mathrm{s} \\
\sum_{j=1}^{n} \lambda_{j}=1 &
\end{array}
$$




$$
\sum_{j=1}^{n} \lambda_{j} \geq 0 \quad \mathrm{j}=1,2 \ldots, \mathrm{n}
$$

Note:

$$
\begin{aligned}
& \pi=\text { efficiency of DMU with BCC method; } \\
& n=\text { total DMUs; } \\
& m=\text { total inputs; } \\
& \mathrm{s}=\text { total outputs; } \\
& \text { xij = total inputs to i DMU } j ; \\
& y r j=\text { total outputs to } r \text { DMU } j ; \\
& \lambda j=\text { weight of DMU j for calculated DMU. }
\end{aligned}
$$

The BCC method is also known as the Variable Return To Scale (VRS) method. This method is done by improving inputs and outputs with unequal proportion. The increased level can be either Increasing Return to Scale (IRS) or Decreasing Return to Scale (DRS). The DEA method has been extensively used in the previous research, especially on analyzing financial institutions. Sherman and Gold (1985) were the first researchers to adopt the DEA to calculate the scores of efficiency of financial institutions. Bhattacharyya et al. (1997) employed the VRS DEA to study commercial financial institutions in India from 1986 to 1991.

\section{RESULTS AND DISCUSSION}

The sample of this research was 22 cooperatives that are located in DKI Jakarta. They were comprised of 11 cooperatives organized by government employees and 11 others managed by the general public. The selection of the sample was not carried out in a random way, but based on the recommendation given by the cooperative head office of Jakarta. The recommendation in question was further made with the following criteria:

- Cooperatives have prepared the financial reports on a yearly basis;

- Cooperatives have met the requirements set by the government, by obtaining the cooperative establishment deeds from the public notaries;

- Cooperatives have organized annual meetings to report their activities to their members.

The presence of descriptive statistics is mainly intended to provide statistical pictures or data descriptions through a table containing information regarding the variables being analyzed. For the descriptive statistical analysis, the data of the input variables was taken from members, capital, and operational costs, while the data of the output variables was sourced from profits, assets, loans, and debt repayments, as shown in Table 2.

Table 2 - Descriptive Statistics

\begin{tabular}{|l|l|l|l|l|l|}
\hline Variable & $N$ & $\min$ & $\max$ & Average & Std. Deviation \\
\hline Members & 132 & 79 & 5731 & 1195.51 & 1170.41 \\
Capital $^{*}$ & 132 & 230153 & 75565086 & 7799449.59 & 1357000.00 \\
Operational costs* $^{*}$ & 132 & 27792 & 32631485 & 2449067.75 & 5843487.42 \\
Profits $^{*}$ & 132 & 6406 & 3541948 & 679238.15 & 821350.79 \\
Assets* $^{*}$ & 132 & 482297 & 191555112 & 23115888.46 & 3892000.00 \\
Loans $^{*}$ & 132 & 428479 & 83894152 & 15482137.51 & 2036000.00 \\
Debt payments & 132 & 405155 & 83881548 & 14406388.15 & 1991000.00 \\
Valid N & 132 & & & & \\
\hline
\end{tabular}

Source: SPPS output (2015).

As presented in Table 2, the difference between the minimum and maximum values was quite substantial, with the values of standard deviation in any variables being so high. This large difference was closely linked to the difference in the size of each saving and loan cooperative. The size refers to the number of its members. In this regard, the more members 
it has, the bigger it will be. Members will affect capital, loans, and profits. This is in line with the previous research conducted by Ni Made Taman Ayuk (2013) on 34 cooperatives in Badung Regency, Bali at a period of 2007-2011. The results showed that the number of members, the amount of savings, the amount of loans, and the amount of capital partially and simultaneously had a significant impact on profits. Likewise, according to a study by Sigit Puji Winarko (2014) on 83 cooperatives located in Kediri, East Java in 2010-2011, the number of members, capital, and assets had a significant and simultaneous effect on profits.

The efficiency test for cooperatives can be done with the DEA method. The input variables were a combined unit of members, capital, and operational costs, and the output variables were a combined unit of profits, assets, loans, and debt repayments. These variables were meant to produce the efficiency values for both types of cooperatives. The results of the efficiency test using the DEA method are shown in Table 3.

Table 3 - Efficiency Values with DEA Approach

\begin{tabular}{|c|c|c|c|}
\hline \multirow[t]{2}{*}{ Code } & \multirow[t]{2}{*}{ Cooperative Name } & \multicolumn{2}{|c|}{$\begin{array}{c}\text { Efficiency value with } \\
\text { DEA (\%) }\end{array}$} \\
\hline & & CRS & VRS \\
\hline KK01 & KPRI RSJ Dr. Suharto Heerjan & 34.65 & 75.23 \\
\hline KK02 & KPRI Rumah Sakit Pelni & 37.08 & 63.64 \\
\hline KK03 & KPRI Primier Mandiri Sejahtera & 43.32 & 62.64 \\
\hline KK04 & KPRI Perum Peruri & 43.63 & 81.7 \\
\hline KK05 & KPRI Departemen Agama Jakarta Selatan & 44.57 & 77.69 \\
\hline KK06 & KPRI Dinas Kebersihan & 48.14 & 75.04 \\
\hline KK07 & KPRI Sekjen Kementerian Pendidikan and Kebudayaan & 40.10 & 53.26 \\
\hline KK08 & KPRI Kementerian Agama RI & 51.54 & 81.21 \\
\hline KK09 & KPRI Primkopal Kolinlamil & 58.12 & 86.76 \\
\hline KK10 & KPRI Guru and Karyawan SMA 45 & 66.6 & 90.75 \\
\hline KK11 & KPRI Kawasan Berikat Nusantara & 59.81 & 85.08 \\
\hline \multicolumn{2}{|r|}{ Total } & 527.48 & 833.03 \\
\hline \multicolumn{2}{|r|}{ Average KK } & 47.95 & 75.73 \\
\hline KM12 & KSP Sumber Jaya & 71.40 & 100 \\
\hline KM13 & KSP Kodanoa & 28.91 & 51.28 \\
\hline KM14 & KSP Sejati Mulya & 54.74 & 74.47 \\
\hline KM15 & KSP Sehati & 29.87 & 61.54 \\
\hline KM16 & KSP Rawa Badung & 35.40 & 55.69 \\
\hline KM17 & KSP Wira Karya Jaya & 72.40 & 100 \\
\hline KM18 & KSP Ceger & 100 & 100 \\
\hline KM19 & KSP Tunas Jaya & 50.89 & 54.21 \\
\hline KM20 & KSP Kesejahteraan Kaum Ibu & 58.47 & 79.47 \\
\hline KM21 & KSP Kemauan Bersama & 100 & 100 \\
\hline KM22 & KSP Makmur & 63.12 & 64.39 \\
\hline \multicolumn{2}{|r|}{ Total } & 665.20 & 841.05 \\
\hline \multirow{2}{*}{\multicolumn{2}{|c|}{$\begin{array}{c}\text { Average KM } \\
\text { Average KK and KM }\end{array}$}} & 60.47 & 76.46 \\
\hline & & 54.21 & 76.10 \\
\hline
\end{tabular}

Source: DEA output (2015).

As provided in Table 3, the calculation of the efficiency value with the DEA method was conducted with two methods, namely Constant Return to Scale (CRS) and Variable Return to Scale (VRS). For cooperatives owned by government employees, the results of calculation with the CRS method showed that the highest efficiency value was achieved by KPRI Guru and Karyawan SMA 45 (66.61\%), followed by KPRI Kawasan Berikat Nusantara (59.81\%), and the lowest efficiency value was obtained by KPRI RSJ Dr Soeharto Heerjan (34.65\%). This means that 11 cooperatives remained inefficient, considering that the average efficiency value still stood at $47.95 \%$.

On the other side, with the VRS method, the highest efficiency value was reached by KPRI Guru and Karyawan SMA 45 (90.75\%), followed by KPRI Primkopal Kolinlamil $(86.76 \%)$, and the lowest efficiency value was owned by KPRI Sekjen Kementerian Pendidikan and Kebudayaan (53.26\%). Due to the average value of efficiency being $75.73 \%$, all cooperatives were still considered inefficient. 
Based on the calculation above, it can be seen that different methods produce different results. The calculation with the VRS method resulted in a greater value than that with the CRS method although both values were under $100 \%$ and considered inefficient.

For cooperatives organized by the general public, the results of measurement with the CRS method indicated that the highest efficiency value was obtained by KSP Ceger and KSP Kemauan Bersama (100\%), followed by KSP Wira Karya Jaya (72.40\%), and the lowest efficiency value was reached by KSP Kodanoa (28.91\%), followed by KSP Sehati $(29,87 \%)$. Although the average efficiency value of 11 cooperatives was $60.47 \%$ or inefficient, two of them were efficient by achieving $100 \%$.

Furthermore, the greatest efficiency value with the VRS method was achieved by KSP Sumber Jaya, KSP Wira Karya Jaya, KSP Ceger, and KSP Kemajuan Bersama (100\%), followed by KSP Kesejahteraan Ibu (79.19\%), and the lowest efficiency value was obtained by KSP Kodanoa (57.27\%). Although the average efficiency value of 11 cooperatives was $76.46 \%$ or inefficient, two of them were efficient by reaching $100 \%$.

As explained earlier, there were two different methods used to calculate the efficiency value, namely CRS and VRS. Since the efficiency value obtained was greater with the VRS method than with the CRS method, the VRS method was better than the CRS method.

The efficiency values between two types of cooperatives were then compared using the DEA method (both CRS and VRS). In terms of having the efficiency value of $100 \%$, there were 2 cooperatives managed by government employees and 4 cooperatives organized by the general public. This means that the later had a better efficiency than the former.

The average efficiency values of 22 cooperatives with the CRS and the VRS were $54.10 \%$ and $76.10 \%$ respectively. Even though these values were below $100 \%$ or inefficient, 5 out of 22 cooperatives reached $100 \%$ or nearly $100 \%$, namely KPRI Guru and Pegawai SMA 45, KSP Sumber Jaya, KSP Wira Karya Jaya, KSP Ceger, and KSP Kemajuan Bersama. In the meantime, 7 cooperatives did not reach the full level of efficiency. This indicated that those cooperatives could not optimize and utilize existing resources to produce optimal outputs. Therefore, they are expected to optimize the operational activities as to achieve $100 \%$ for the efficiency value in the future.

This is in line with the previous research by Rohmah (2014), which found that 4 out of 21 cooperatives were not efficient because of the excessive use of inputs. The inefficiency is closely adherent to the use of employee needs, and they are recommended to improve the performance and optimize the use of capital.

Table 4 - Efficiency Values with DEA Approach (CRS and VRS)

One-Sample Statistics

\begin{tabular}{|l|l|l|l|l|}
\hline & N & Mean & Std. Deviation & Std. Error Mean \\
\hline Test of DEA_CRS KK and KM & 22 & .542164 & .1946635 & .0415024 \\
Test of DEA_VRS KK and KM & 22 & .760932 & .1616671 & .0344675 \\
\hline
\end{tabular}

One-Sample Test

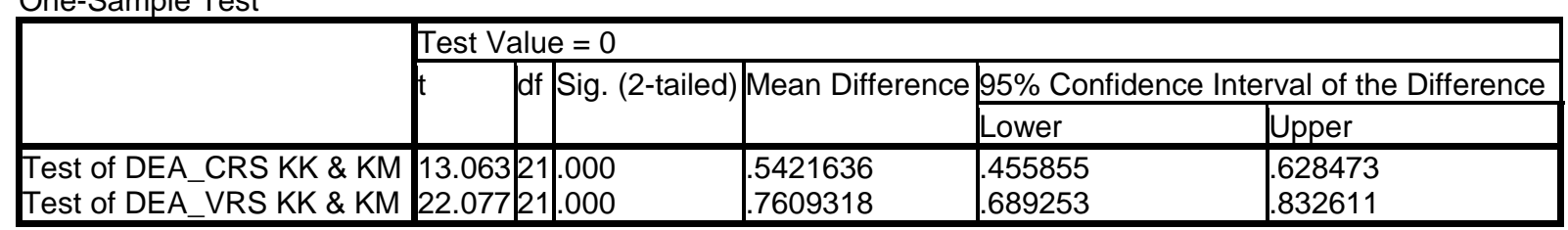

Source: SPSS output (2015).

As presented in Table 4, the results of testing the efficiency values of saving and credit cooperatives owned by government employees and by the general public with the CRS showed that the $t$ statistical value $>t$ table or the level of significance $0.000<0.05$ means that there was difference in the efficiency values between those two types of cooperatives.

On the other hand, the results of testing the efficiency values of saving and credit cooperatives possessed by government employees and by the general public with the VRS 
indicated that the $t$ statistical value $>t$ table or the level of significance $0.000<0.05$ means that there was difference in the efficiency value between those two types of cooperatives.

\section{CONCLUSION}

Based on the results of the DEA approach (CRS and VRS), 4 cooperatives managed by the general public succeeded to achieve the efficiency value of $100 \%$, namely KSP Sumber Jaya, KSP Wira Karya Jaya, KSP Ceger, and KSP Kemajuan Bersama, and 1 cooperative organized by government employees reached the efficiency value of nearly $100 \%$, namely KPRI Guru and Pegawai SMA 45 (90.75\%). The results also showed that the average values of 22 cooperatives were $76.10 \%$ with the VRS and $54.10 \%$ with the CRS. Therefore, it can be concluded that the efficiency value of cooperatives managed by the general public was better than that of cooperatives organized by government employees, and 17 out of 22 cooperatives in DKI Jakarta were inefficient.

\section{SUGGESTIONS}

Based on the results of this research, a set of recommendations is offered to cooperatives in order to operate efficiently and effectively.

First, the cooperatives have yet to publish the condition openly, especially in terms of financial reports. This will affect the public trust in the cooperatives, and the general public will not be interested to be their members. The progress of a cooperative depends on the number of its members. The more members it has, the better it will become. The progress of a cooperative also connects with its capital as a financial source from its members, following that they are obliged to pay principal fees, mandatory fees, and voluntary contributions.

Second, the cooperatives owned by government employees have grown slowly. This is different from what happens to the cooperatives established by the general public. The underlying cause is that such cooperatives rely largely on the government, where the number of members will increase due to the addition of employees. In fact, some cooperatives have witnessed a decrease in the number of members. On the other side, cooperatives owned by the general public have experienced over years. Consequently, the better their services are, the faster the number of members will increase.

The cooperative management differs between both types of cooperatives. In cooperatives owned by government employees, the management handled by non cooperative members leads to providing salaries, thus increasing the operating costs and reducing profits.

\section{LIMITATIONS AND RECOMMENDATIONS}

This research has several limitations and problems that are noticable and unavoidable. The limitations encountered by researchers are related to the data of the research. The data of the cooperatives, particularly the financial reports, are not open for either research or public use. This is different from the financial reports of banks whose reports are made available for the public. The data of this research was obtained directly from the sample cooperatives, and it had to be approved by the cooperative head office of Jakarta. The head office subsequently determined which cooperatives could be used as the sample for this research.

The data was collected over a period of 7 months. The issue was stemmed from the availability of the data in the head office. Some of the data was incomplete and not suitable to be used as variables. This research was conducted in Central Jakarta, South Jakarta, East Jakarta, North Jakarta, and West Jakarta. The researchers came directly to the cooperatives recommended by the office of cooperatives in each region, along with the recommendation letter written by it.

Despite the recommendation letters, the cooperative parties held internal meetings with their cooperative management to get approval. This stage took a long time, and the 
researchers had to visit the cooperatives frequently in order to collect the data. It is expected that the government will make a policy on the openness of the data, so the general public has access to the state of a cooperative. Considering these limitations, comprehensive research on cooperatives in Indonesia remains inadequate and limited in general, including urban and individual cooperatives.

It is then recommended for future researchers to increase research on saving and credit cooperatives. In this regard, the researchers of this study have not conducted research in the scopes of cities or provinces, due to the difficulty of obtaining the data. Unlike banks, local cooperatives have not provided the public with access to their financial reports through websites. Therefore, in-depth research into cooperatives cannot be carried out by universities as a result from the data limitations. The data may only be concentrated within the government which tends to have no capability to produce a comprehensive analysis using various econometric methods.

Based on the limitations discussed above, the recommendations are given as follows. First, the government should immediately introduce a policy which encourages cooperatives to provide clear and reliable information regarding their financial reports and other matters related to their operations. In this way, a comprehensive study on cooperatives can be conducted, and the findings of the study can be applied more broadly. Second, the government should invite cooperatives to provide information and data on their profiles and financial reports through online platforms. As a consequence, research will be cost and time efficient. Third, the government can give incentives to cooperatives that provide complete information and initiate to widen the distribution channels of the data to the public, thus stimulating the development of scientific studies which will in turn benefit many parties.

\section{REFERENCES}

1. Al-Jarrah, I., \& Molyneux, P. (2006). Cost efficiency, scale elasticity and scale economies in Arab banking. Banks and Bank Systems, 1(3), 60-89.

2. Ascarya, Achsani, N. A., Yumanita, D., \& Rokhimah, G. S. (2009). Positioning Analysis of Islamic Bank vis-à- vis Conventional Bank in Indonesia using Parametric SFA and DFA Methods. Islamic Finance \& Business Review, 4(2), 785-807. https://dx.doi.org/10.30993/tifbr.v4i2.36.

3. Banker, R. D., Charnes, A., \& Cooper, W. W. (1984). Some models for estimating technical and scale inefficiencies in data envelopment analysis. Management Science, 30(9), 1078-1092. https://doi.org/https://doi.org/10.1287/mnsc.30.9.1078.

4. Benston, G. J., Hunter, W. C., \& Wall, L. D. (1995). Motivations for Bank Mergers and Acquisitions: Enhancing the Deposit Insurance Put Option versus Earnings Diversification Author ( $s$ ): George J . Benston, William C . Hunter and Larry D . Wall Published by: Ohio State University Press Stable URL : htt. Journal of Money, Credit and Banking, 27(3), 777-788. https://doi.org/https://doi.org/10.2307/2077749.

5. Berger, A. N., \& Humphrey, D. B. (1997). Efficiency of Financial Institutions: International Survey and Directions for Future Research. European Journal of Operational Research, 98(2), 175-212. https://doi.org/https://doi.org/10.1016/S0377-2217(96)00342-6.

6. Charnes, A., Cooper, W. W., \& Rhodes, E. (1978). Measuring the efficiency of decision making units. European Journal of Operational Research, 2(6), 429-444. https://doi.org/10.1016/0377-2217(78)90138-8.

7. Demirbag, M., Tatoglu, E., Glaister, K. W., \& Zaim, S. (2010). Measuring strategic decision making efficiency in different country contexts: A comparison of British and Turkish firms. Omega, 38(1-2), 95-104. https://doi.org/10.1016/j.omega.2009.05.001.

8. Ferhi, A., \& Chkoundali, R. (2015). Comparing Effectiveness between Islamic and Conventional Bank during the Current Crises. Intellectual Property Rights: Open Access, 3(1), 1-11. https://doi.org/10.4172/2375-4516.1000139.

9. Freixas, X., \& Rochet, J. C. (1998). Fair pricing of deposit insurance. Is it possible? Yes. Is it desirable? No. Research in Economics, 52(3), 217-232. https://doi.org/10.1006/reec.1998.0164. 
10. Ivan, I.-C. (2015). Stochastic Frontiers. Case Study - Japanese Banking System. Procedia Economics and Finance, 27(15), 652-658. https://doi.org/10.1016/s22125671(15)01045-x.

11. Jemric, I., \& Vujcic, B. (2002). Efficiency of Banks in Croatia: A DEA Approach. Comparative Economic Studies, 44(2-3), 169-193. https://doi.org/10.1057/ces.2002.13.

12. Karimah, S., Novianti, T., \& Effendi, J. (2016). Kajian Efisiensi Bank Umum Syariah di Indonesia. Al-Muzara'ah, 4(1), 33-43. https://doi.org/10.29244/jam.4.1.33-43.

13. Kuosmanen, T., Saastamoinen, A., \& Sipiläinen, T. (2013). What is the best practice for benchmark regulation of electricity distribution? Comparison of DEA, SFA and StoNED methods. Energy Policy, 61, 740-750. https://doi.org/10.1016/j.enpol.2013.05.091.

14. Majid, M. Z. A., \& Sufian, F. (2006). Consolidation and competition in emerging market: An empirical test for Malaysian banking industry. Economic Change and Restructuring, 39(1-2), 105-124. https://doi.org/10.1007/s10644-007-9022-4.

15. Mamatzakis, E., Tsionas, M. G., Kumbhakar, S. C., \& Koutsomanoli-Filippaki, A. (2015). Does labour regulation affect technical and allocative efficiency? Evidence from the banking industry. Journal of Banking and Finance, 61, S84-S98. https://doi.org/10.1016/j.jbankfin.2015.06.012.

16. Mhembwe, S., \& Dube, E. (2017). The role of cooperatives in sustaining the livelihoods of rural communities: The case of rural cooperatives in. Jàmbá: Journal of Disaster Risk Studies, 9(1), 1-9. https://doi.org/https://doi.org/10.4102/jamba.v9i1.341.

17. Oh, S. C., \& Shin, J. (2015). The impact of mismeasurement in performance benchmarking: A Monte Carlo comparison of SFA and DEA with different multi-period budgeting strategies. European Journal of Operational Research, 240(2), 518-527. https://doi.org/10.1016/j.ejor.2014.07.026.

18. Saeed, S., Ali, F., \& Baber Adeeb, M. H. (2013). Examining efficiency of Islamic and conventional banks in Pakistan: using data envelopment analysis. Global Journal of Management and Business Research, 13(10).

19. Santoso, A. L., \& Sukihanjani, T. (2013). Faktor-Faktor yang Mempengaruhi Likuiditas Perbankan Syariah di Indonesia. Jurnal Ekonomi Universitas Sebelas Maret, 3(1), 221-231.

20. Sokic, A. (2015). Cost efficiency of the banking industry and unilateral euroisation: A stochastic frontier approach in Serbia and Montenegro. Economic Systems, 39(3), 541551. https://doi.org/10.1016/j.ecosys.2015.01.006.

21. Titko, J., \& Jureviciene, D. (2014). DEA Application at Cross-country Benchmarking: Latvian vs Lithuanian Banking Sector. Procedia - Social and Behavioral Sciences, 110, 1124-1135. https://doi.org/10.1016/j.sbspro.2013.12.959.

22. Ueasin, N., Liao, S. Y., \& Wongchai, A. (2015). The Technical Efficiency of Rice Husk Power Generation in Thailand: Comparing Data Envelopment Analysis and Stochastic Frontier Analysis. Energy Procedia, 75, 2757-2763. https://doi.org/10.1016/j.egypro.2015.07.518.

23. Zuhroh, I., Ismail, M., \& Maskie, G. (2015). Cost Efficiency of Islamic Banks in Indonesia - A Stochastic Frontier Analysis. Procedia - Social and Behavioral Sciences, 211, 11221131. https://doi.org/10.1016/j.sbspro.2015.11.150. 